\title{
Implementation methodology of practices based on scientific evidence for assistance in natural delivery: a pilot study
}

\author{
Metodologia de implementação de práticas baseadas em evidências \\ científicas na assistência ao parto normal: estudo piloto \\ Metodología de implantación de prácticas basadas en evidencias \\ científicas en la asistencia al parto normal: estudio piloto
}

Clodoaldo Tentes Côrtes ${ }^{1,2}$, Rafael Cleison Silva dos Santos ${ }^{1.2}$, Adriana de Souza Caroci ${ }^{3}$, Sheyla Guimarães Oliveira ${ }^{1}$, Sonia Maria Junqueira Vasconcelos de Oliveira ${ }^{4}$, Maria Luiza Gonzalez Riesco ${ }^{4}$

${ }^{1}$ Universidade de São Paulo, Escola de Enfermagem, Programa de Pós-Graduação em Enfermagem, São Paulo, SP, Brazil.

${ }^{2}$ Universidade Federal do Amapá, Curso de Graduação em Enfermagem, Macapá, AP, Brazil.

${ }^{3}$ Universidade de São Paulo, Curso de Obstetrícia, Escola de Artes, Ciências e Humanidades, São Paulo, SP, Brazil.

${ }^{4}$ Universidade de São Paulo, Escola de Enfermagem, Departamento de Enfermagem Materno-Infantil e Psiquiátrica, São Paulo, SP, Brazil.

\begin{abstract}
Objective: Presenting methodology for transferring knowledge to improve maternal outcomes in natural delivery based on scientific evidence. Method: An intervention study conducted in the maternity hospital of Itapecerica da Serra, SP, with 50 puerperal women and 102 medical records from July to November 2014. The PACES tool from Joanna Briggs Institute, consisting of pre-clinical audit (phase 1), implementation of best practice (phase 2) and Follow-up Clinical Audit (phase 3) was used. Data were analyzed by comparing results of phases 1 and 3 with Fisher's exact test and a significance level of $5 \%$. Results: The vertical position was adopted by the majority of puerperal women with statistical difference between phases 1 and 3. A significant increase in bathing/showering, walking and massages for pain relief was found from the medical records. No statistical difference was found in other practices and outcomes. Barriers and difficulties in the implementation of evidence-based practices have been identified. Variables were refined, techniques and data collection instruments were verified, and an intervention proposal was made. Conclusion: The study found possibilities for implementing a methodology of practices based on scientific evidence for assistance in natural delivery.
\end{abstract}

\section{DESCRIPTORS}

Evidence-Based Practice; Clinic Audit; Natural Childbirth; Obstetric Nursing. 


\section{INTRODUCTION}

The importance of basing health care practice on the best evidence available and of translating knowledge or evidence into action has been increasingly emphasized in most countries ${ }^{(1-3)}$.

Results from the research Nascer no Brasil (Born in Brazil) conclude that Brazilian women are exposed to unnecessary interventions. For women who are in an underprivileged socio-economic situation, there was greater use of painful procedures, but on the other hand, they had more access to good practices in labor and delivery. Therefore, it is important to empower women and promote evidence-based practices and strategies to improve the model of obstetric care, promoting evidence-based practice and improving the quality of life and health of its population ${ }^{(4)}$.

Care based on evidence originates from clinical issues related to health needs. From these matters, knowledge and evidence are generated through research. Other components of this process are: 1) evaluation and synthesis of evidence generated by research; 2) transfer and use of evidence in practice; 3) evaluation of the impact of using evidence for improving health ${ }^{(5)}$.

While conducting primary research and systematic reviews are essential to scientific progress in health, components 2 and 3 of this process are a major challenge to the achievement of scientific evidence based care.

Several theories that address the transfer of knowledge, also called science of translation, or translational research, isolate this cycle process of Evidence-Based Practice (EBP) in two ways: the transfer of findings from basic science or laboratory research to develop new interventions tested by clinical trials; and the transfer of proven knowledge for use in clinical practice. While the first mode of transferring relates to the traditional paradigm of scientific research, the second involves the active participation and collaboration of all those concerned in the methodological development to communicate knowledge and articulate research questions. The gaps in these two transfer modes are the main obstacles reported in the literature ${ }^{(1)}$.

Translating knowledge into action in health care is a complex dynamic process, constantly evolving. Several models have been described; however, a standard acceptable approach has yet to be widely adapted. Whatever approach or model used, there are essentially three critical gaps associated with the transfer of knowledge for improving health outcomes and quality of services. Gap 1 is regarding the distance between knowledge that needs to be identified by patients, health professionals, governments and organizations, and the work done by scientists and researchers. This gap is a vital component of translational research and has been little studied by a few groups, with the exception being the National Institute for Health Research in the UK. Gap two refers to the distance between theoretical, epidemiological and laboratory research and clinical research. This is the most commonly addressed gap at an international level with significant production in several countries; however for many, this is where translational research begins and ends. Gap three is considered essential, but rarely addressed; it refers to the distance between clinical application of research results and the development of conducts, actions and health policies ${ }^{(1)}$.

Also, a key challenge in nursing for evidence-based care is its implementation. Misinterpretations and claims such as evidence-based practice is notbing new, it leads to mass nursing, disregarding individualized care with an overemphasis on randomized controlled trials and irrelevant systematic reviews for nursing represent barriers and are often responsible for the difficulty of promoting changes to professional practice ${ }^{(6)}$. In general, these claims are related to a lack of motivation and conviction about the value of research to nursing practice. However, there are also barriers related to the lack of organizational support, nurses' autonomy for care and the lack of continuing education for behavioral change.

Introducing practices that are based on scientific evidence require more than knowledge and convictions because they involve behavioral change, overcoming barriers and filling in gaps in knowledge transfer.

Traditionally, education is the most widely used approach to stimulate change and improvement. The effectiveness of educational interventions to implement effective care and reduce unnecessary procedures varies. Approaches on a small scale, such as workshops, training and educational meetings where participation is usually active and interactive may be more effective, however there is little research evidence to support this ${ }^{(7)}$.

There is a growing consensus that producing evidence of effective interventions and practices is not enough, or even evidence of cost-effectiveness so that better care in labor and delivery is provided ${ }^{(8)}$. In turn, the contributions of evidence syntheses - systematic reviews and meta-analyzes - should be highlighted ${ }^{(9)}$. Several services, including hospitals, maternity wards and Normal Childbirth Centers (NCC) are incorporating the results of these studies, and nurses and midwives have important participation in its implementation in labor and birth assistance.

The objective of this study is to present a knowledge transfer methodology in order to improve maternal outcomes related to good care practices in natural delivery based on scientific evidence. It also has the purpose to serve as a pilot study to test tools, techniques and interventions for future research for improving maternal and neonatal outcomes.

\section{METHOD}

This is a before-and-after quasi-experimental intervention study, according to the implementation methodology of scientific evidence in clinical practice from the Joanna Briggs Institute (JBI) based in Adelaide, Australia. This methodology consists of a clinical audit process and adopts the PACES tool - Practical Application of Clinical Evidence System, which is comprised of three phases: 1) pre-clinical audit; 2) implementation of best practices; 3) post-implementation audit.

In phase 1, the topic to be audited/evaluated must be well-defined and the audit/evaluation team should be established, including stakeholders (meaning users and ser- 
vice professionals), and in particular key-professionals. These professionals represent people involved in the management and assistance process, who depend on the barriers and amenities found at the Institute for the development of the project. Examples include the directors and coordinators who enable the necessary conditions for the project, leaders and students who contribute to disseminating the project, and users who provide feedback related to results. Even at this stage, the criteria for auditing/evaluation should be identified and baseline audit is performed to obtain the parameters to be evaluated after the implementation of the practices. By using PACES, the sample of professionals and users, as well as the criteria and parameters to be analyzed are generated.

In phase 2, PACES features a software called Getting Research Into Practice (GRIP), used to document the barriers encountered, strategies for the implementation of practices and resources needed to overcome obstacles.

Phase 3 is based on the criteria and parameters identified in phase 1.

The study was conducted at the Normal Childbirth Center (NCC) of the Municipal Emergency Room and Maternity Zoraide Eva das Dores (MERMZED), an institution linked to the Municipal Health Municipality of Itapecerica da Serra, Sao Paulo. The NCC, characterized by the intra-hospital model, attends to pregnant women of normal risk and is organized in the PPP system (prepartum, partum and post-partum), where women stay from their admission until up to two hours after giving birth. After this period, puerperal woman and newborns are referred to the shared rooms. In 2013, the monthly average of births was 106 , with $74 \%$ being natural deliveries and $25.2 \%$ episiotomies. For every shift, the health care team is composed of two obstetric nurses, two obstetricians, one anesthesiologist and one pediatrician, as well as technicians and nursing assistants.

Obstetric nurses perform all natural deliveries without dystocia. Obstetricians are responsible for hospitalizing women in labor, assist in operative and dystocia labors and evaluate complications. Professionals are advised to follow the recommendations of the World Health Organization and the Ministry of Health, avoiding routine use of episiotomy and intravenous infusion of oxytocin. Non-drug methods are used for pain relief and interaction between mother and child in the first half hour of life is stimulated. The diet is open, and the women are allowed a companion of their choice.

The population consisted of puerperal women and medical records of women attending the service.

Data collection was carried out in three phases according to PACES in the period of July to November 2014.

In phase 1, pre-clinical audit, interviews were conducted with 25 puerperal women and data were collected from 51 medical records of puerperal women not interviewed, with structured instruments specifically designed for the study to identify the practices used in natural delivery assistance in the repair of perineal trauma and preliminary assessment of outcomes. The women were personally interviewed in the first or second day of postpartum hospitalization. The director of the service who authorized the data collection also participated, and informed the staff about the project as a strategy to increase study adherence.

Phase 2, related to the implementation of best practices, consisted of an educational intervention through a workshop held for nurses and obstetricians. 15 professionals attended the workshop; six midwives and nine obstetricians. This workshop took place in a single day lasting four hours in the auditorium of City Hall, three weeks after the completion of phase 1. Its purpose was to present and discuss the scientific evidence and best practices in relation to the promotion of natural birth available in scientific literature, in order to raise awareness and update the professionals of its implementation. The program consisted of presenting results of the pre-clinical audit conducted by director of MERMZED, and discussions of the scientific evidence, including an illustrative video projection on the perineal suturing technique. Systematic reviews from the Cochrane Library reading materials and relevant clinical trials were made available.

In phase 3, a post-implementation audit was performed 30 days after the workshop, through interviews with 25 different puerperal women from those interviewed in phase 1 , and data were collected from 51 medical charts of non-interviewed puerperal women, using the same tools of Phase 1. At this stage, the mothers were personally interviewed between the first and second day of postpartum hospitalization. The purpose was to evaluate the impact of the educational intervention for the implementation of best practices in natural delivery assistance and repair of perineal trauma.

The study included the following practices and outcomes in delivery and childbirth care: prescription, administration and indication for intravenous infusion of oxytocin; nonpharmacological methods of pain relief during labor, such as showering, walking, massage and use of a Bobath Ball; birthing position; choice of birthing position by childbearing women; kind of pushing; anesthesia used in childbirth; perineal trauma; perineal repair; technique and suture material used; spontaneous pain in the perineal suture (not when performing activities); pain in the perineal suture during daily activities; need for postpartum analgesia and women's satisfaction with perineal repair.

Data analysis was performed by comparing the results of phases 1 and 3, before and after intervention. Fisher's two-tailed exact test was used on both samples (of puerperal women and medical records), considering $\mathrm{p}$ values lower than 0.05 being statistically significant.

The study was approved by the Ethics Research Committee of the University of São Paulo School of Nursing (CAAE: 31700414.50000.5392) and authorized by the Municipal Health Council of Itapecerica da Serra. The participation of professionals and women was volunteered at every stage of the research, after reading and signing the Informed Consent Form and Minor Consent Term, where appropriate.

\section{RESULTS}

Tables 1 and 2 show the analysis results of practices and maternal outcomes identified in 102 medical records and 
interviews with 50 puerperal women between the first and second day of postpartum.

Table 1 shows that among the 25 participating puerperal women in pre-clinical audit, 24 (96\%) pregnant women were prescribed oxytocin, and after the intervention, there was a decrease to 20 (80\%), but without significant statistical difference. Although there was also no statistically significant difference, walking and massage during labor were the non-pharmacological methods of pain relief most commonly used after the intervention. The semi-seated, seated or squatting positions were adopted by most women, while the lithotomy position was not used by any of the women after the procedure with a statistically significant difference between phases 1 and 3. More women reported using guided pushing, 24 (96\%) versus 20 (80\%) after the intervention, with this not being a significant statistical difference. There were more reports of spontaneous pain in the perineal suturing $(10(40 \%)$ to $1(4 \%))$ in the postintervention audit, which was statistically significant. It is worth mentioning that the proportion of women with sutured perineal trauma was higher in phase 3. On the other hand, perineal suture pain complaints during activities showed no significant increase in the post-intervention audit. The proportion of women somewhat satisfied or dissatisfied with the perineal conditions decreased, but with no statistically significant difference.

Table 1 - Distribution of maternal outcomes identified in interviews with the puerperal women in pre-clinical audit (phase 1) and post-intervention audit (phase 3) and p-values - Itapecerica da Serra, SP, Brazil, 2014.

\begin{tabular}{|c|c|c|c|c|c|}
\hline \multirow{3}{*}{ Variable } & \multicolumn{4}{|c|}{ Puerperal women } & \multirow{3}{*}{ p-value* } \\
\hline & \multicolumn{2}{|c|}{ Phase 1} & \multicolumn{2}{|c|}{ Phase 3} & \\
\hline & $\mathbf{n}$ & $\%$ & $\mathbf{n}$ & $\%$ & \\
\hline Medical prescription of oxytocin & 25 & & 25 & & \multirow{3}{*}{0.189} \\
\hline Yes & 24 & 96.0 & 20 & 80.0 & \\
\hline No & 1 & 4.0 & 5 & 20.0 & \\
\hline \multicolumn{6}{|l|}{ Non-pharmacological methods of pain relief } \\
\hline Showering & 18 & 72.0 & 17 & 68.0 & 1.000 \\
\hline Walking & 12 & 48.0 & 17 & 68.0 & 0.252 \\
\hline Massage & 3 & 12.0 & 7 & 28.0 & 0.289 \\
\hline Bobath ball & 5 & 20.0 & 5 & 20.0 & 1.000 \\
\hline Position in childbirth & 25 & & 25 & & \multirow{5}{*}{0.001} \\
\hline Semi-seated or seated & 17 & 68.0 & 16 & 64.0 & \\
\hline Lithotomic & 7 & 28.0 & - & - & \\
\hline Sideways/lateral & 1 & 4.0 & 5 & 20.0 & \\
\hline Squatting & - & - & 4 & 16.0 & \\
\hline Choice of position by the parturient/women & 25 & & 25 & & \\
\hline Yes & 7 & 28.0 & 7 & 28.0 & \multirow{2}{*}{1.000} \\
\hline No & 18 & 72.0 & 18 & 72.0 & \\
\hline Guided pushing & 25 & & 25 & & \\
\hline Yes & 20 & 80.0 & 24 & 96.0 & \multirow{2}{*}{0.189} \\
\hline No & 5 & 20.0 & 1 & 4.0 & \\
\hline Use of anesthesia in childbirth & 20 & & 19 & & \\
\hline Yes & 19 & 95.0 & 18 & 94.7 & \multirow{2}{*}{1.000} \\
\hline No & 1 & 5.0 & 1 & 5.3 & \\
\hline Spontaneous pain in perineal suturing & 19 & & 18 & & \\
\hline Yes & 1 & 5.3 & 10 & 55.6 & \multirow{2}{*}{0.001} \\
\hline No & 18 & 94.7 & 8 & 44.4 & \\
\hline Pain in perineal suturing during activities & 19 & & 18 & & \multirow{6}{*}{0.633} \\
\hline Walking or sitting & 8 & 42.1 & 5 & 27.8 & \\
\hline Urinating or evacuating & 2 & 10.5 & 2 & 11.1 & \\
\hline Walking, sitting, urinating and evacuating & 4 & 21.0 & 6 & 33.3 & \\
\hline $\begin{array}{l}\text { Walking, sitting, urinating, evacuating and } \\
\text { breastfeeding }\end{array}$ & 1 & 5.3 & 3 & 16.7 & \\
\hline No pain & 4 & 21.0 & 2 & 11.1 & \\
\hline Postpartum analgesic (pain relieve) & 19 & & 18 & & \\
\hline Yes & 11 & 57.9 & 12 & 66.7 & \multirow{2}{*}{0.737} \\
\hline No & 8 & 42.1 & 6 & 33.3 & \\
\hline
\end{tabular}




\begin{tabular}{|c|c|c|c|c|c|}
\hline \multirow{3}{*}{ Variable } & \multicolumn{4}{|c|}{ Puerperal women } & \multirow{3}{*}{ p-value } \\
\hline & \multicolumn{2}{|c|}{ Phase 1} & \multicolumn{2}{|c|}{ Phase 3} & \\
\hline & $\mathbf{n}$ & $\%$ & $\mathbf{n}$ & $\%$ & \\
\hline Satisfaction with the perineal repair & 19 & & 18 & & \\
\hline Very satisfied & 1 & 5.3 & 2 & 11.1 & \\
\hline Satisfied & 8 & 42.1 & 9 & 50.0 & \\
\hline Somewhat satisfied & 4 & 21.0 & 2 & 11.1 & 0.653 \\
\hline Unsatisfied & 3 & 15.8 & 1 & 5.6 & \\
\hline Not informed & 3 & 15.8 & 4 & 22.2 & \\
\hline
\end{tabular}

*Fisher's exact test

Based on data from medical records, Table 2 shows that the use of showering, walking and massages for pain relief in labor significantly increased after the intervention. For other practices and outcomes, there was no statistically significant difference.

Table 2 - Distribution of maternal outcomes identified in the medical records at the clinic pre-audit (phase 1) and post-intervention audit (phase 3) and p-value - Itapecerica da Serra, SP, Brazil, in 2014.

\begin{tabular}{|c|c|c|c|c|c|}
\hline \multirow{3}{*}{ Variable } & \multicolumn{4}{|c|}{ Puerperal women } & \multirow{3}{*}{ p--value* } \\
\hline & \multicolumn{2}{|c|}{ Phase 1} & \multicolumn{2}{|c|}{ Phase 3} & \\
\hline & $\mathbf{n}$ & $\%$ & $\mathbf{n}$ & $\%$ & \\
\hline Intravenous infusion of oxytocin & 51 & & 51 & & \multirow{3}{*}{0.654} \\
\hline Yes & 36 & 70.6 & 39 & 74.5 & \\
\hline No & 15 & 29.4 & 12 & 25.5 & \\
\hline \multicolumn{6}{|l|}{ Non-pharmacological methods of pain relief } \\
\hline Showering & 20 & 39.2 & 33 & 64.7 & 0.000 \\
\hline Walking & 16 & 31.4 & 32 & 62.7 & 0.000 \\
\hline Massage & 15 & 29.4 & 28 & 54.9 & 0.000 \\
\hline Bobath ball & 15 & 29.4 & 16 & 31.4 & 0.163 \\
\hline Position in childbirth & 51 & & 51 & & \multirow{6}{*}{0.678} \\
\hline Semi-seated or seated & 33 & 64.7 & 40 & 78.4 & \\
\hline Sideways/lateral & 10 & 19.6 & 6 & 11.8 & \\
\hline Lithotomic & 1 & 2.0 & 1 & 2.0 & \\
\hline No records & 7 & 13.7 & 4 & 7.8 & \\
\hline Perineum & 51 & & 51 & & \\
\hline Laceration & 29 & 56.9 & 31 & 60.8 & \multirow{3}{*}{0.647} \\
\hline Intact & 15 & 29.4 & 11 & 21.6 & \\
\hline Episiotomy with or without laceration & 7 & 13.7 & 9 & 17.6 & \\
\hline Degree of perineal laceration & 29 & & 31 & & \multirow{4}{*}{0.382} \\
\hline First & 20 & 69.0 & 25 & 80.0 & \\
\hline Second & 9 & 31.0 & 6 & 20.0 & \\
\hline Repair of perineal lacerations & 29 & & 31 & & \\
\hline Yes & 3 & 10.3 & 13 & 41.9 & \multirow{3}{*}{0.235} \\
\hline No & 1 & 3.4 & - & - & \\
\hline No records & 25 & 86.3 & 18 & 58.1 & \\
\hline
\end{tabular}


The variables administration and medical indication for intravenous infusion of oxytocin and method and suture material used in the perineal repair were not analyzed due to the lack of information in the medical records.

\section{DISCUSSION}

This study presents an implementation methodology for practices based on scientific evidence in natural delivery assistance, which consisted of three phases: 1) pre-clinical audit; 2) implementation of best practices; 3) post-implementation audit. This research allowed for testing this methodology, obtaining the parameters to be evaluated after the implementation of educational interventions on best practices in natural delivery assistance.

Regarding maternal outcomes identified in interviews with the mothers, it was observed that one of the practices with a statistically significant difference between phases 1 and 3 was the position taken by the woman in childbirth. Semi-sitting, sitting or squatting positions were adopted by most of the women in the second stage, while lithotomic was not mentioned by any of them after the intervention. This position had been used in $28 \%$ of deliveries in the pre-audit. The adoption of the lateral position increased fivefold, while squatting only occurred in the post-intervention audit. In a systematic review of different positions of the mother in the pushing period without epidural anesthesia that included 22 clinical trials and 7,280 women, the authors concluded that there were benefits to the upright position in natural deliveries because there was a significant reduction in assisted deliveries and fewer abnormal patterns of fetal heart rates ${ }^{(10)}$.

Another result that showed statistically significant difference in the interview with the mothers was the complaint of spontaneous pain in the perineal suturing. Some papers report that the type of suture and the thread used in the perineal repair, among other factors, appear to be related to pain in this region. A systematic Cochrane Review of 16 studies with 8184 women from eight countries compared two methods of suture used in episiotomy and second degree lacerations, observing that the continuous suture technique was associated with less pain, and less need for analgesia and suture removal when compared to the traditional interrupted technique ${ }^{(11)}$. As for suture material, another systematic review of 18 studies and 10,171 women showed that catgut sutures had increased complaints of perineal pain in the postpartum compared to synthetic absorbable sutures ${ }^{(12)}$.

It deserves mentioning that the proportion of puerperal women with sutured perineal trauma was about four times higher in phase 3 when compared to phase 1, although the results did not show a statistically significant difference. However, because the information came from medical record annotations, it is not possible to ensure the reliability of this variable, considering the high number of absent records in the two phases of research.

The other outcomes reported by the puerperal women, such as the need for analgesic and satisfaction with perineal repair, among others, did not show a statistically significant difference. However, it is worth highlighting that the satisfaction of puerperal women with the perineum achieved bet- ter impact in the post-intervention audit, especially among those who were very satisfied (increase of 5.3\% to $11.1 \%$ ) and somewhat/little satisfied ( $21 \%$ reduction to $11.1 \%)$. Thus, it is understood that the most relevant results for these outcomes can be explained by the action, almost exclusively, of obstetric nurses in the NCC and for their commitment to the implementation of evidence-based practice, as they demonstrated better knowledge and greater interest compared to doctors who attended the workshop in fewer numbers.

A longitudinal study conducted in the UK in 22 maternity services which considered the intervention of a training program for midwives and doctors, and also supported the evaluation of the implementation and repair of second-degree perineal laceration and episiotomies based on scientific evidence to improve clinical practice, found that most participants improved their experience and reported having used practices based on scientific evidence for perineal repair after training. Therefore, the results showed that the educational intervention significantly improved the knowledge of professionals about the best perineal repair practices based on evidence, concluding that the permanent and standardized education is essential for the maintenance of improved care ${ }^{(13)}$.

However, in the current study the results identified in the medical records showed that perineal lacerations and episiotomy rates increased by around four percentage points after the proposed intervention, but without a statistically significant difference. Moreover, it was not possible to determine how many mothers needed repair due to the lack of registration of such information in some records, as previously mentioned. These data indicate that the implementation of evidence-based practices through the workshop did not improve some of the assessed outcomes. Among the factors involved, it is believed that the low adherence of professionals, being both doctors and midwives, during the workshop of good practices might not have contributed more significant results by changing the belief of some that episiotomy protects the perineum against other diseases, and also to the decreased use of the lateral position during delivery (19.6\% to $11.8 \%$ ).

The result of this study is similar the one found by a retrospective survey conducted in nine services in four Southeast Asian countries, which analyzed the episiotomy practices before and after a multicomponent intervention. The authors evaluated the influence of training on using evidence about the practice of episiotomy and perineal trauma. In this study, some centers participating in the survey reported increased episiotomy rates, because each center had implemented its intervention with varied emphases on specific practices, depending on the perceived needs. They identified a number of barriers to the practice of restrictive episiotomy, which included: fear of tearing, difficulty in repairing lacerations compared to episiotomies, lack of preparation of the perineum, applicability of the research conducted in a different population, lack of time and the need to train the young/newer staff ${ }^{(14)}$.

There was also a change in obstetric practice in a randomized controlled clinical trial with 600 nulliparous women in Iran comparing perineal protection techniques (hands on intervention technique of perineal protection and hands off - expectant technique of perineal protection) by the reduction of perineal traumas. The authors concluded that there were 
more cases of episiotomy and third-degree perineal lacerations with the hands on technique than hands off(15).

An analysis of the medical records showed that the practicing of non-pharmacological pain relief methods was adopted more after the intervention. It was found that the shower bath movement during labor and massage was most often practiced, with a statistically significant increase, which varied between $25 \%$ and $31 \%$. These practices are considered simple, inexpensive and easy to apply therapeutic methods that help the mother to reduce stress, fear and pain, thereby providing comfort and favoring the formation of a relationship with the nursing team.

Bathing with warm water, either in a shower or a bath, is an intervention that has been widely used in childbirth assistance. Hot baths are a non-invasive strategy of cutaneous stimulation with superficial heat, producing local and general effects, which is why it is considered a complementary and alternative treatment in obstetric practice. At an average temperature of $37^{\circ} \mathrm{C}$, a bath is associated with the relief of pain and anxiety during labor, reducing levels of neuroendocrine stress-related hormones, improving the standard of uterine contractions and therefore correcting uterine dystocia ${ }^{(16)}$.

In addition to the positive effects of physical hygiene, for its cost-effectiveness and facility to implement, showering is a non-pharmacological approach to pain relief that provides autonomy to the woman in labor, provides continuous caregiver support and a more positive experience in childbirth ${ }^{(17)}$.

The incentive to non-supine positions and freedom of position and movement during childbirth labor are demonstrably useful practices and should be encouraged. The World Health Organization recommends that women adopt their position of their preference in either the first or the second stage of labor, as long as they avoid long periods in the supine position. Professionals should encourage the upright position that causes less discomfort and difficulty in pushing, less pain during labor and less vaginal or perineal trauma during expulsion ${ }^{(2,18)}$.

A systematic review of the Cochrane Library with 5,218 women in labor summarized the findings of 25 studies on maternal positions and walking during the first stage of labor. Authors concluded that there is significant evidence that walking and upright positions in the dilating phase reduces the duration of labor, the risk of caesarean section, and the need for epidural analgesia, which seems to be associated with increased adverse effects on mothers and babies. It is recommended that, if possible, women are encouraged to walk and use the vertical position of their choice, as this can improve progress in labor and lead to better maternal and fetal outcomes ${ }^{(19)}$.

In turn, a randomized clinical trial with 95 participants, both men and women, showed that massage increases blood levels of oxytocin and decreases the levels of adrenocorticotropic hormone and beta-endorphin ${ }^{(20)}$. Moreover, another systematic review was developed with the purpose of elucidating the effects of massage and other non-pharmacological methods, such as reflexology. This Cochrane review summarized that women who received massage reported less pain and anxiety during labor when compared to women who received usual care. The authors concluded that massage can play an important role in reducing pain, improving the experience of pregnant women, however, also ratifying the need for further research on this approach ${ }^{(21)}$.

This study found that despite MERMZED having protocols for adoption of best practices, these are not followed by all professionals, and the service presents inadequacies in the care provided to natural deliveries.

A clinical audit study conducted with 9,550 medical records of women in labor in nine hospitals in four Southeast Asian countries showed that few audited practices in the perinatal care were consistent with the best available evidence. This audit was used to propose an implementation project of clinical practice based on evidence, called SEA-ORCHID (South East Asia Optimising Reproductive and Child Health In Developing countries). The authors confirmed limitations due to the lack of adequate records of the practices in the medical records; however, they consider that this limitation was minimized by standardization of medical records in relation to researched practices and prospective data collection ${ }^{(22)}$.

In this study, the improvement of maternal outcomes recorded in the medical records in the post-intervention audit (stage 3) may be due to both the increased use of good obstetric practices and the improvement in their own records. This is a limitation related to secondary data sources. Other limitations are the lack of sample size calculation, convenience sample and no randomization of the puerperal women included in the study.

The methodology employed attaches importance to participation of professionals in phases 1 and 3 , through interviews and observation of adopted practices. However, health professionals only participated in phases 1 and 2. Although the project had been previously presented to the obstetric nurses and doctors as a strategy for increasing adherence, there were difficulties in collecting data. Specially designed questionnaires for data collection on the practice of these professionals were answered only in phase 1 , with much resistance from the medical team, despite the availability of researchers to conduct interviews during all work shifts. Therefore, data obtained from the professionals have not been integrated into this study.

As previously mentioned in the Method section, phase 2 consisted of a workshop on best practices in natural delivery. On that occasion, the director of the maternity hospital presented the pre-audit statistics (phase 1) to the health professionals. As a limitation, it is important to note that the participation of professionals was restricted/low (five obstetric nurses and two doctors), even though certificates of participation and compensation for participation outside of working hours were offered to the doctors by the local Health Authority of Itapecerica da Serra. It is believed that the support of a trained facilitating doctor who is welcome to changes in adherence at the study site can help these professionals, as some doctors reported that they would not like to be trained by nurses.

It is also worth considering that in addition to barriers related to the childbirth assistance model and of the service itself to the implementation of best practices, previous educational experiences of professionals and different teaching strategies should also be considered. In this sense, the impact of educational interventions in changing behavior of profes- 
sionals can vary, considering that this is formed more from beliefs, attitudes and experiences than from scientific evidence ${ }^{(23)}$.

Another key aspect refers to maintaining practices after their implementation. A study on implementation of care in the prevention of nipple trauma for breastfeeding promotion conducted in a university hospital in São Paulo using the same JBI-PACES tool emphasized that the commitment to maintaining evidence-based practice should be continued in order to sustain these improvements in the future ${ }^{(24)}$.

Finally, it is worth noting that this pilot study brought contributions to assisting in the design, sampling, validation techniques and data collection instruments, definition of interventions and refinement of the variables for the research to be held in a public maternity hospital of Amapa.

\section{CONCLUSION}

The impact of this project, being the implementation of practices based on scientific evidence in natural childbirth as- sistance, was considered positive because data regarding interviews of puerperal women after the intervention showed more use of upright and lateral positions in delivery and no use of the lithotomy position. With regard to non-pharmacological methods of pain relief, there were more women who walked and received massages, thereby feeling reduced pain in these points when walking or sitting, and reported greater satisfaction with perineal repair. On the other hand, most women reported spontaneous pain at the sutured site.

In relation to data from medical records, there was a reduction in the use of the lateral position, increased use of oxytocin, increased perineal trauma, a greater need for analgesia, a higher record of non-pharmacological use of pain relief and more puerperal women who underwent perineal laceration repair.

We propose the implementation of practices based on scientific evidence in natural childbirth assistance, using the same methodology of JBI, to improve the professional health practices of a public hospital in the city of Macapa, Amapá, Brazil.

\section{RESUMO}

Objetivo: Apresentar metodologia de transferência do conhecimento para melhorar desfechos maternos no parto normal com base em evidências científicas. Método: Estudo de intervenção realizado em maternidade de Itapecerica da Serra, SP, com 50 puérperas e 102 prontuários de julho a novembro de 2014. Utilizada a ferramenta PACES, do Instituto Joanna Briggs, que consiste de préauditoria clínica (fase 1), implementação de boas práticas (fase 2) e auditoria pós-implementação (fase 3). Analisaram-se os dados, comparando resultados das fases 1 e 3 com teste exato de Fisher e nível de significância 5\%. Resultados: A posição vertical foi adotada pela maioria das puérperas com diferença estatística entre as fases 1 e 3. Pelos prontuários, verificou-se um aumento significativo de banho, deambulação e massagem para alívio da dor. Nas demais práticas e desfechos, não houve diferença estatística. Identificaram-se barreiras e dificuldades para a implementação da prática baseada em evidências. Realizou-se refinamento das variáveis e validação das técnicas e instrumentos de coleta de dados e da intervenção proposta. Conclusão: $O$ estudo apontou possibilidades da metodologia de implementação de práticas baseadas em evidências científicas na assistência ao parto normal.

\section{DESCRITORES}

Prática Clínica Baseada em Evidências; Auditoria Clínica; Parto Normal; Enfermagem Obstétrica.

\section{RESUMEN}

Objetivo: Presentar metodología de transferencia del conocimiento para mejorar los resultados maternos en el parto normal en base a evidencias científicas. Método: Estudio de intervención llevado a cabo en maternidad de Itapecerica da Serra, SP, con 50 puérperas y 102 fichas clínicas de julio a noviembre de 2014. Se utilizó la herramienta PACES, del Instituto Joanna Briggs, que consiste de pre auditoría clínica (fase 1), implantación de buenas prácticas (fase 2) y auditoría post implantación (fase 3). Se analizaron los datos, comparando resultados de las fases 1 y 3 con prueba exacta de Fisher y nivel de significación del 5\%. Resultados: La posición vertical fue adoptada por la mayoría de las puérperas con diferencia estadística entre las fases 1 y 3 . Por las fichas, se verificó un incremento significativo de baño, deambulación y masaje para alivio del dolor. En las demás prácticas y resultados, no hubo diferencia estadística. Se identificaron las barreras y dificultades para la implantación de la práctica basada en evidencias. Se hizo el refinamiento de las variables y la validación de las técnicas e instrumentos de recolección de datos y la intervención propuesta. Conclusión: El estudio señaló posibilidades de la metodología de implantación de prácticas basadas en evidencias científicas en la asistencia al parto normal.

\section{DESCRIPTORES}

Práctica Clínica Basada en la Evidencia; Auditoría Clínica; Parto Normal; Enfermería Obstétrica.

\section{REFERENCES}

1. Pearson A, Jordan Z, Munn Z. Translational science and evidence-based healthcare: a clarification and reconceptualization of how knowledge is generated and used in healthcare. Nurs Res Pract [Internet]. 2012 [cited 2015 Feb 19]:792519. Available from: http://www. hindawi.com/journals/nrp/2012/792519/

2. Brasil. Ministério da Saúde; Secretaria de Políticas de Saúde, Área Técnica de Saúde da Mulher. Parto, aborto e puerpério: assistência humanizada à mulher. Brasília; 2006.

3. Lobo SF, Oliveira SMJV, Schneck CA, Silva FMB, Bonadio IC, Riesco MLG. Maternal and perinatal outcomes of an alongside hospital birth center in the city of São Paulo, Brazil. Rev Esc Enferm USP [Internet]. 2010 [cited 2015 Feb 19];44(3):812-8. Available from: http://www. scielo.br/pdf/reeusp/v44n3/en_37.pdf 
4. Leal MC, Pereira APE, Domingues RMSM, Theme Filha MM, Dias MAB, Pereira MN, et al. Obstetric interventions during labor and childbirth in Brazilian low-risk women. Cad Saúde Pública. 2014;30 Supl. 1:S17-32.

5. Pearson A, Wiechula R, Court A, Lockwood C. The JBI model of evidence-based healthcare. Int J Evid Based Healthc. 2005;3(8):207-15.

6. Cullum N, Ciliska D, Haynes RB, Marks S. Enfermagem baseada em evidências. Porto Alegre: Artmed; 2010.

7. Wensing M, Grol R. Educational interventions. In: Grol R, Wensing M, Eccles M. Improving patient care: the implementation of change in clinical practice. Oxford: Elsevier; 2005.

8. Riesco MLG, Oliveira SMJV. Enfermagem baseada em evidências científicas: um enfoque assistencial. In: Associação Brasileira de Enfermagem; Associação Brasileira de Obstetrizes e Enfermeiras Obstétricas. PROENF: saúde materna e neonatal. Porto Alegre: Artmed; 2010.

9. Pearson A. Evidence synthesis and its role in evidence-based health care. Nurs Clin North Am. 2014;49(4):453-60.

10. Gupta JK, Hofmeyr GJ, Shehmar M. Position in the second stage of labour for women without epidural anaesthesia. Cochrane Database Syst Rev. 2012;(5):CD002006.

11. Kettle C, Dowswell T, Ismail KM. Continuous versus interrupted sutures for repair of episiotomy or second degree tears. Cochrane Database Syst Rev. 2012;(11):CD000947.

12. Kettle C, Dowswell T, Ismail KM. Absorbable suture materials for primary repair of episiotomy and second degree tears. Cochrane Database Syst Rev. 2010;(6):CD000006.

13. Ismail KMK, Kettle C, Macdonald SE, Tohill S, Thomas PW, Bick D. Perineal Assessment and Repair Longitudinal Study (PEARLS): a matchedpair cluster randomized trial. BMC Med. 2013;11:209.

14. Ho JJ, Pattanittum P, Japaraj RP, Turner T, Swadpanich U, Crowther CA. Influence of training in the use and generation of evidence on episiotomy practice and perineal trauma. Int J Gynaecol Obstet. 2010;111(1-9):13-8.

15. Rezaei R, Saatsaz S, Chan YH, Nia HS. A comparison of the "hands-off" and "hands-on" methods to reduce perineal lacerations: a randomised clinical trial. J Obstet Gynaecol India. 2014;64(6):425-9.

16. Benfield RD, Hortobagyi T, Tanner CJ, Swanson M, Heitkemper MM, Newton ER. The effects of hydrotherapy on anxiety, pain, neuroendocrine responses and contraction dynamics during labor. Biol Res Nurs. 2010;12(1):28-36.

17. Lee SL, Liu CY, Lu YY, Gau ML. Efficacy of warm showers on labor pain and birth experiences during the first labor stage. J Obstet Gynecol Neonatal Nurs. 2013;42(1):19-28.

18. Organização Mundial de Saúde (OMS). Assistência ao parto normal: um guia prático. Brasília: OPAS/USAID: 1996. [OMS/SRF/MSM/96.24].

19. Lawrence A, Lewis L, Hofmeyr GJ, Styles C. Maternal positions and mobility during first stage labour. Cochrane Database of Syst Rev. 2013;(8):CD003934.

20. Morhenn V, Beavin LE, Zak PJ. Massage increases oxytocin and reduces adrenocorticotropin hormone in humans. Altern Ther Health Med. 2012;18(6):11-8.

21. Smith CA, Levett KM, Collins CT, Jones L. Massage, reflexology and other manual methods for painmanagement in labour. Cochrane Database of Syst Rev. 2012;(2):CD009290.

22. Sea-Orchid Study Group. Laopaiboon M, Lumbiganon P, McDonald SJ, Henderson-Smart DJ, Green S, Crowther CA. Use of evidencebased practices in pregnancy and childbirth: South East Asia Optimising Reproductive and Child Health in Developing countries project. PLoS One. 2008;3(7):e2646.

23. Bastos MHS. Developing and pilot-testing an educational intervention to reduce the routine performance of episiotomy in Brazil [thesis]. London: Thames Valley University, 2011. Available from: http://ethos.bl.uk/OrderDetails.do?uin=uk.bl.ethos.534484.

24. Shimoda GT, Soares AVN, Aragaki IMM, McArthur A. Preventing nipple trauma in lactating women in the University Hospital of the University of Sao Paulo: a best practice implementation project. JBI Database Syst Rev Implement Rep. 2015;13(2):212-32. 